\title{
Epiphytic Survival of Erwinia tracheiphila on Muskmelon (Cucumis melo L.)
}

\author{
E. Saalau Rojas and M. L. Gleason, Department of Plant Pathology, Iowa State University, Ames 50010
}

\begin{abstract}
Saalau Rojas, E., and Gleason, M. L. 2012. Epiphytic survival of Erwinia tracheiphila on muskmelon (Cucumis melo L.). Plant Dis. 96:62-66.

Erwinia tracheiphila, the causal agent of bacterial wilt of cucurbits, is transmitted by striped (Acalymma vittatum) and spotted (Diabrotica undecimpunctata howardi) cucumber beetles. Transmission occurs when infested frass with E. tracheiphila is deposited on plant surfaces with fresh feeding wounds. However, it is unclear whether the pathogen can survive as an epiphyte on leaves. Experiments were conducted in controlled environments to monitor E. tracheiphila survival on muskmelon (Cucumis melo) leaves under various temperature and moisture conditions. In the first experiment, muskmelon seedlings that had been spray inoculated with a rifampicin-resistant strain of $E$. tracheiphila were incubated at $10,15,20,25,30$, or $35^{\circ} \mathrm{C}\left( \pm 2^{\circ} \mathrm{C}\right)$ at $\geq 95 \%$

72 h. In the second experiment, E. tracheiphila was monitored during alternating 12-h wet and dry periods, or continuous wet or dry conditions for $48 \mathrm{~h}$ at $20^{\circ} \mathrm{C}$. Survival of E. tracheiphila on wet muskmelon leaves depended on temperature $(P<0.01)$, with the greatest survival at 10 and $15^{\circ} \mathrm{C}$ and least at 30 and $35^{\circ} \mathrm{C}$. Leaf wetness also impacted survival; an initial 12-h dry period resulted in a 1,000- to 10,000-fold reduction in population size, followed by stabilization of the surviving population. These results demonstrate that E. tracheiphila can survive on muskmelon leaves under a wide range of environmental conditions, suggesting that epiphytic populations might serve as a reservoir of inoculum for infections.
\end{abstract} relative humidity, and E. tracheiphila populations were monitored for
Bacterial wilt caused by Erwinia tracheiphila is a major challenge for cucurbit growers in the eastern half of the United States $(11,23,24)$. Bacterial wilt impacts all cucurbit crops except watermelon. In muskmelon (Cucumis melo L.), for example, yield losses can be as high as $80 \%$ (23). The United States is one of the major producers of cantaloupe and melon (Cucumis spp.) worldwide, with a farm gate value of approximately $\$ 400$ million in 2009 (31).

Striped (Acalymma vittatum (F.)) and spotted (Diabrotica undecimpunctata howardi (Barber)) cucumber beetles transmit $E$. tracheiphila $(12,29,34)$. The pathogen overwinters in adult beetles $(12,14,33)$. Transmission occurs when adults feed on plants; inoculum from infested frass enters freshly wounded tissues $(5,6,22$, $28,29,34$ ) on leaves, stems, or nectaries of flowers (38). Bacteria enter the vascular system via these openings, multiply, and produce exopolysaccharides, which eventually block water flow to the rest of the plant (38). Symptoms include wilting of leaves and vines followed by collapse of the entire plant.

Management strategies against bacterial wilt focus primarily on controlling the vectors by insecticide applications $(7,9,11,13)$. However, this dependency on insecticides can create hazards for growers, consumers, pollinators, and the environment $(7,13,16,18)$. Alternative strategies such as row covers $(19,29,37)$, perimeter trap crops $(1,10,35)$, and kairomonal baits $(17,27)$ can reduce the risk of bacterial wilt but they can be labor intensive and require further validation before they can be used reliably by growers.

Lack of understanding of E. tracheiphila ecology and epidemiology is a barrier to developing effective ecologically based alternatives for bacterial wilt management. One reason for this poor understanding is that E. tracheiphila is difficult to isolate and maintain in culture. Unlike several other important Erwinia sp. phytopathogens, E. tracheiphila grows slowly in culture and can rapidly lose viability (9). As a result, the potential role of epiphytic populations of E. tracheiphila in the disease cycle remains largely unexplored. Epiphytic populations can serve as primary inoculum for development of epidemics in many bacterial pathosystems

Corresponding author: M. L. Gleason, E-mail: mgleason@iastate.edu

Accepted for publication 1 August 2011.

http://dx.doi.org/10.1094/PDIS-04-11-0277

(C) 2012 The American Phytopathological Society
$(3,15,35)$, and characterizing the environmental biology of the epiphytic phase has facilitated development of more effective management strategies. For example, monitoring epiphytic populations of the fire blight pathogen E. amylovora has been essential for determining the risk of disease epidemics, improving biological control methods, and timing antibiotic applications $(20,21,39,42)$.

Experiments by Brust (6) provided indirect evidence that E. tracheiphila might have an epiphytic phase on cucurbit crops. These experiments suggested that E. tracheiphila could survive for up to $6 \mathrm{~h}$ on muskmelon leaf surfaces, and that these populations could infect plants after leaves were wounded. Mitchell and Hanks (29) confirmed that E. tracheiphila could survive in beetle frass and retain viability as inoculum for up to $24 \mathrm{~h}$ after the bacterium was ingested by striped cucumber beetles.

The impact of environmental conditions on epiphytic survival of E. tracheiphila is also poorly understood. It is reasonable to assume that E. tracheiphila could be dispersed from frass deposits to other sites on leaf surfaces by rain or dew, potentially resulting in infection via wounds. Moist weather conditions may also favor infection by E. tracheiphila (34), as suggested by the common association of moist conditions with bacterial wilt development (41). The purpose of the present study was to evaluate whether $E$. tracheiphila survives on muskmelon leaves, and to assess how survival is influenced by temperature and fluctuating moisture conditions.

\section{Materials and Methods}

Plant growth conditions. Muskmelon seed ('Athena') were planted in 233- $\mathrm{cm}^{3}$ pots (Nu-Pot 3; Summit Plastic Co., Akron, $\mathrm{OH} ; 40 \%$ peat moss, $40 \%$ prepared substrate [Sunshine Mix SB300; Sun Gro Horticulture Canada Ltd., Vancouver, BC Canada], and $20 \%$ coarse perlite). They were incubated for 12 to 15 days at $25^{\circ} \mathrm{C}$ under a regime of $12 \mathrm{~h}$ of light and $12 \mathrm{~h}$ of darkness in a growth chamber (Model PGW36; Conviron, Winnipeg, AB, Canada) until unfolding of the first true leaf. After emergence, seedlings were thinned to one per pot.

Bacterial strain and growth conditions. A naturally occurring rifampicin-resistant strain of E. tracheiphila, SCR3, was isolated from a wilting muskmelon plant in Iowa in 2009. Colonies that resembled E. tracheiphila in morphology (9) were confirmed positive by polymerase chain reaction (PCR) using E. tracheiphilaspecific primers ETC1and ETC2 (28). Colonies were selected for rifampicin resistance $(75 \mu \mathrm{g} / \mathrm{ml})$ and stored at $-80^{\circ} \mathrm{C}$ in Luria-Ber- 
tani broth containing $25 \%$ glycerol. In order to fulfill Koch's postulates, 2-week-old muskmelon plants were puncture inoculated with SCR3 strain. Bacterial colonies were suspended in sterile 10 $\mathrm{mM}$ phosphate-buffered saline (PBS) solution $(\mathrm{pH} 7.4)$ and concentration was adjusted to $10^{8} \mathrm{CFU} / \mathrm{ml}$. A $100-\mu \mathrm{l}$ aliquot of the suspension was spread on the first true leaf of seedlings and leaves were punctured using a pin frog. Wilt symptoms were assessed and the strain was reisolated from symptomatic plants.

Inoculum preparation. Strain SCR3 was recovered from $-80^{\circ} \mathrm{C}$ 1 week prior to inoculum preparation, streaked onto nutrient agar peptone (NAP) plates amended with rifampicin at $75 \mu \mathrm{g} / \mathrm{ml}$, and incubated at $26^{\circ} \mathrm{C}$ in darkness. Cultures were incubated for 4 days, then restreaked onto fresh NAP plates 3 days before inoculum preparation. Inoculum was prepared by suspending strain SCR3, grown on NAP, in $10 \mathrm{mM}$ PBS solution ( $\mathrm{pH} 7.4)$ and adjusting the concentration to approximately $10^{8} \mathrm{CFU} / \mathrm{ml}$. Cell concentrations were calculated based on optical density in a spectrophotometer at $540 \mathrm{~nm}$ according to a standard curve for E. tracheiphila.

Influence of temperature on epiphytic survival. Twelve pots, each containing one muskmelon plant, were evenly spaced in each of four 25-pot trays (Nu-tray 3-25; Summit Plastic Co.). Plants with a fully unfolded first true leaf were spray inoculated until runoff with inoculum using a hand-trigger sprayer (model $916 \mathrm{CN}$; Contico International, St. Louis). Immediately after inoculation, trays were placed in dew chambers (model I60DL; Percival International, Perry, IA) and incubated for $72 \mathrm{~h}$ at 10, 15, 20, 25, 30 , or $35^{\circ} \mathrm{C}\left( \pm 2^{\circ} \mathrm{C}\right)$ and a regime of $12 \mathrm{~h}$ of light and $12 \mathrm{~h}$ of darkness under conditions $(\geq 95 \%$ relative humidity $[\mathrm{RH}])$ conducive to dew formation. The experimental design was a split-plot, randomized complete block in which temperature was the whole-plot treatment randomly assigned to a dew chamber in a run, and sampling time was the subplot treatment randomly assigned to a leaf in a tray. Temperature and RH were recorded hourly using WatchDog Data Loggers (model 150; Spectrum Technologies, Plainfield, IL). At each sampling time, two arbitrarily selected leaves, each from a different plant, were excised from each tray. In total, eight leaves per sampling time were removed at $0,12,24,36,48$, and $72 \mathrm{~h}$ after inoculation. Each excised leaf was immersed in $20 \mathrm{ml}$ of $0.1 \mathrm{M}$ PBS (pH $7.4+0.01 \%$ peptone [wt/vol]) in sterile 50-ml polypropylene centrifuge tubes (Corning Inc., Corning, NY), then sonicated (model Branson 200; Branson Ultrasonic Corp., Danbury, $\mathrm{CT}$ ) for $7 \mathrm{~min}$ and mixed by vortexing for $15 \mathrm{~s}$. Fivefold dilutions of each leaf washing were plated onto NAP amended with rifampicin at $75 \mu \mathrm{g} / \mathrm{ml}$ and cycloheximide at $100 \mu \mathrm{g} / \mathrm{ml}$. Leaves were removed from the centrifuge tubes and allowed to air dry on paper towels for $15 \mathrm{~min}$ before weighing. After 5 days at $26^{\circ} \mathrm{C}$ in darkness, colonies of E. tracheiphila were counted and expressed as CFU per gram of fresh leaf weight. The experiment was performed twice.
Epiphytic survival during intermittent wet and dry periods. To determine epiphytic survival of E. tracheiphila under wetting and drying conditions resembling those that occur under field conditions, plants were spray inoculated as previously described and maintained at $20^{\circ} \mathrm{C}$ throughout the experiment. In order to create different wetness regimes, plants were incubated for $48 \mathrm{~h}$ in
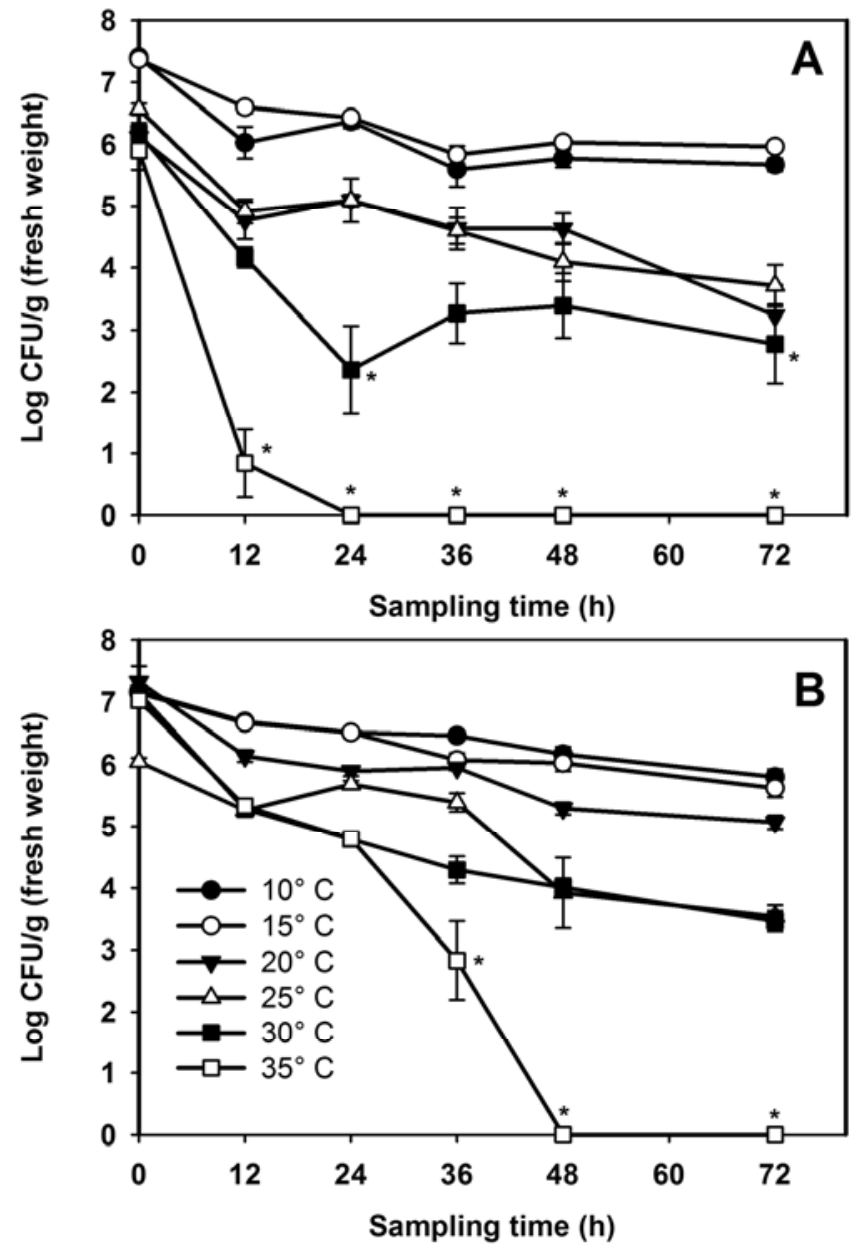

Fig. 1. Epiphytic populations (expressed as $\log _{10}$ CFU per gram of fresh leaf weight) of Erwinia tracheiphila strain SCR3 on muskmelon leaves incubated for 72 $\mathrm{h}$ under wet conditions at six different temperatures. The experiment was performed twice; each data point in $\mathbf{A}$, first run and $\mathbf{B}$, second run represents the mean \pm standard error of eight leaves. Means below the detection limit $2.88\left(\log _{10}\right.$ $\mathrm{CFU} / \mathrm{g}$ fresh weight) are indicated by an asterisk $\left(^{*}\right)$.

Table 1. Summary of analysis of variance of epiphytic populations of Erwinia tracheiphila on muskmelon leaves under different temperature treatments and intermittent wet and dry periods ${ }^{\mathrm{u}}$

\begin{tabular}{|c|c|c|c|c|}
\hline Survival, source & $\mathbf{d f}^{\mathbf{v}}$ & Error $^{w}$ & $F$ value & $P>F$ \\
\hline \multicolumn{5}{|l|}{ Survival at different temperatures } \\
\hline $\operatorname{Run}^{\mathrm{x}}$ & 1 & Run $\times$ temperature & 8.56 & 0.0328 \\
\hline Temperaturey & 5 & Run $\times$ temperature & 19.93 & 0.0026 \\
\hline Sampling time ${ }^{\mathrm{z}}$ & 5 & Residual error & 253.47 & $<0.0001$ \\
\hline Temperature $\times$ sampling time & 25 & Residual error & 8.23 & $<0.0001$ \\
\hline \multicolumn{5}{|c|}{ Survival under intermittent wet/dry periods } \\
\hline $\operatorname{Run}^{\mathrm{x}}$ & 1 & Run $\times$ treatment & 18.00 & 0.0240 \\
\hline Treatment ${ }^{\mathrm{y}}$ & 3 & Run $\times$ treatment & 83.89 & 0.0022 \\
\hline Sampling time ${ }^{\mathrm{z}}$ & 3 & Residual error & 497.47 & $<0.0001$ \\
\hline Treatment $\times$ sampling time & 9 & Residual error & 47.14 & $<0.0001$ \\
\hline
\end{tabular}

" Mean square error with residual error values was $24.4 \pm 1.47$ for survival at different temperatures and $0.66 \pm 0.28$ for survival under different wetness regimes.

${ }^{v}$ Degrees of freedom.

${ }^{\text {w}}$ Error term used to test run of the experiment multiplied by temperature treatment and run of the experiment multiplied by wetness regime treatment.

${ }^{x}$ Run of each experiment.

${ }^{\mathrm{y}}$ Temperature in growth chambers or dew chambers.

${ }^{\mathrm{z}}$ Time at which leaves were sampled after inoculation. 
a dew chamber $(\geq 95 \% \mathrm{RH})$ in darkness or a growth chamber $(\geq 30 \% \mathrm{RH})$ in the light as follows: continuous wet or dry conditions, 12-h wet periods alternated with 12 -h dry periods, or $12-\mathrm{h}$ dry periods alternated with 12 -h wet periods. The experimental design was a split-plot, randomized complete block in which wetness regime was the whole-plot treatment randomly assigned to a chamber in a run, and sampling time was the subplot treatment randomly assigned to a leaf in a tray. In total, eight leaves were excised at each sampling time $(0,12,24$, and $48 \mathrm{~h}$ after inoculation). After sonication and vortexing, E. tracheiphila populations were enumerated as described above. The experiment was performed twice.

Statistical analysis. In each experiment, colony counts were normalized to CFU per gram of fresh leaf weight by $\log _{10}$ transformation. For both experiments, transformed data were compared by analysis of variance (ANOVA) using PROC MIXED (version 9.1; SAS Institute Inc., Cary, NC). The whole-plot treatment (temperature or wetness regime) was tested against the whole-plot error, run $\times$ temperature, split-plot treatment, and sampling time, and interactions were tested against the residual error. Area under the curve (AUC) values were estimated from average populations $\left(\log _{10}\right.$ $\mathrm{CFU} / \mathrm{g}$ fresh weight) determined at each sampling time in each experiment. AUC values were analyzed in a one-way ANOVA using PROC GLM (SAS Institute Inc.).

\section{Results}

Impact of temperature on epiphytic survival. Survival of $E$. tracheiphila on muskmelon leaves was impacted by temperature (Table 1). By $12 \mathrm{~h}$ after inoculation, population size had decreased significantly at all temperatures (Fig. 1$)(P<0.01)$. There was no significant change in population size at either 10 or $15^{\circ} \mathrm{C}$ between 12 and $72 \mathrm{~h}$ after inoculation. The population sizes at the midrange temperatures plateaued after $12 \mathrm{~h}$ but then decreased significantly by $36 \mathrm{~h}\left(25^{\circ} \mathrm{C}\right)$ and $72 \mathrm{~h}\left(20^{\circ} \mathrm{C}\right)$. E. tracheiphila populations declined rapidly and continuously for $24 \mathrm{~h}$ at $30^{\circ} \mathrm{C}$ and for up to $72 \mathrm{~h}$ at $35^{\circ} \mathrm{C}$. Values of AUC indicated that survival at 10 and $15^{\circ} \mathrm{C}$ exceeded that at $20,25,30$, and $35^{\circ} \mathrm{C}$, whereas AUC values at midrange temperatures were similar to each other (Table 2).

Impact of intermittent wet and dry periods on epiphytic survival. Survival of E. tracheiphila on muskmelon leaves was impacted by wetness regime (Table 1). The presence or absence of wetness on leaves significantly impacted survival during the first $12 \mathrm{~h}$ after inoculation (Fig. 2). Survival was significantly higher

Table 2. Comparison of area under the curve (AUC) values for epiphytic survival of Erwinia tracheiphila on muskmelon leaves under different temperature treatments and intermittent wet and dry periods

\begin{tabular}{|c|c|}
\hline Treatment & $\mathbf{A U C}^{\mathbf{s}}$ \\
\hline \multicolumn{2}{|l|}{ Temperature $\left({ }^{\circ} \mathrm{C}\right)^{\mathrm{t}}$} \\
\hline 10 & $450.3 \mathrm{a}$ \\
\hline 15 & $446.0 \mathrm{a}$ \\
\hline 20 & $378.0 \mathrm{~b}$ \\
\hline 25 & $341.9 \mathrm{bc}$ \\
\hline 30 & $306.8 \mathrm{~cd}$ \\
\hline 35 & $259.5 \mathrm{~d}$ \\
\hline $\mathrm{LSD}^{\mathrm{u}}$ & 51.3 \\
\hline \multicolumn{2}{|c|}{ Intermittent wet/dry periods $\mathrm{v}$} \\
\hline $12 \mathrm{~h}$ wet/12 h dryw & $229.4 \mathrm{~b}$ \\
\hline 12 dry/12 h wet ${ }^{\mathrm{x}}$ & $184.6 \mathrm{c}$ \\
\hline $48 \mathrm{~h} \mathrm{wet}^{\mathrm{y}}$ & $285.7 \mathrm{a}$ \\
\hline 48 h dry ${ }^{z}$ & $170.9 \mathrm{c}$ \\
\hline LSD & 18.9 \\
\hline \multicolumn{2}{|c|}{$\begin{array}{l}{ }^{\mathrm{s}} \log _{10} \text { of AUC. Means in the same column followed by the sam } \\
\text { not significantly different }(P=0.05) . \\
{ }^{\mathrm{t}} \text { Under wet conditions }(\geq 95 \% \text { relative humidity) for } 72 \mathrm{~h} . \\
\text { u } \mathrm{LSD}=\text { least significant difference }(P=0.05) . \\
{ }^{\mathrm{v}} \text { At } 20^{\circ} \mathrm{C} \text { for } 48 \mathrm{~h} \text {. } \\
{ }^{\mathrm{w}} \text { Schedule of } 12 \text {-h wet periods alternated with } 12 \text {-h dry periods. } \\
{ }^{\mathrm{x}} \text { Schedule of } 12 \text {-h dry periods alternated with } 12 \text {-h wet periods. } \\
{ }^{y} \text { Continuous wetness. } \\
{ }^{z} \text { Continuous dryness. }\end{array}$} \\
\hline
\end{tabular}

under continuous wet conditions and lowest when plants were initially exposed to dry conditions (Table 2). During an initial 12-h dry period, populations fell by more than three orders of magnitude. A similar population decline occurred when plants initially exposed to wet conditions were subsequently exposed to dry conditions for $12 \mathrm{~h}$. Population level stabilized after an initial decline associated with the first dry period, despite later recurrence of dry periods. No differences were observed between AUC values when plants were exposed to an initial 12-h dry period after inoculation or when they were exposed to dry conditions throughout the entire experiment.

\section{Discussion}

Our findings provide the first direct evidence that E. tracheiphila can survive for at least several days on muskmelon leaves. In the only previous study of epiphytic survival, Brust (6) demonstrated that placement of $E$. tracheiphila inoculum on muskmelon leaves followed by wounding up to $6 \mathrm{~h}$ later could result in wilting.

Although E. tracheiphila is known primarily as a vascular pathogen, our findings suggest that it is also persistent and resilient as an epiphyte. High temperatures and exposure to dry periods clearly reduced survival of E. tracheiphila, whereas continuous wetness at optimum temperatures $\left(10\right.$ to $20^{\circ} \mathrm{C}$ ) clearly favored survival. These surviving populations could become important sources of inoculum, particularly if leaves become wounded by subsequent events such as high winds or insect feeding. Relatively low survival at 30
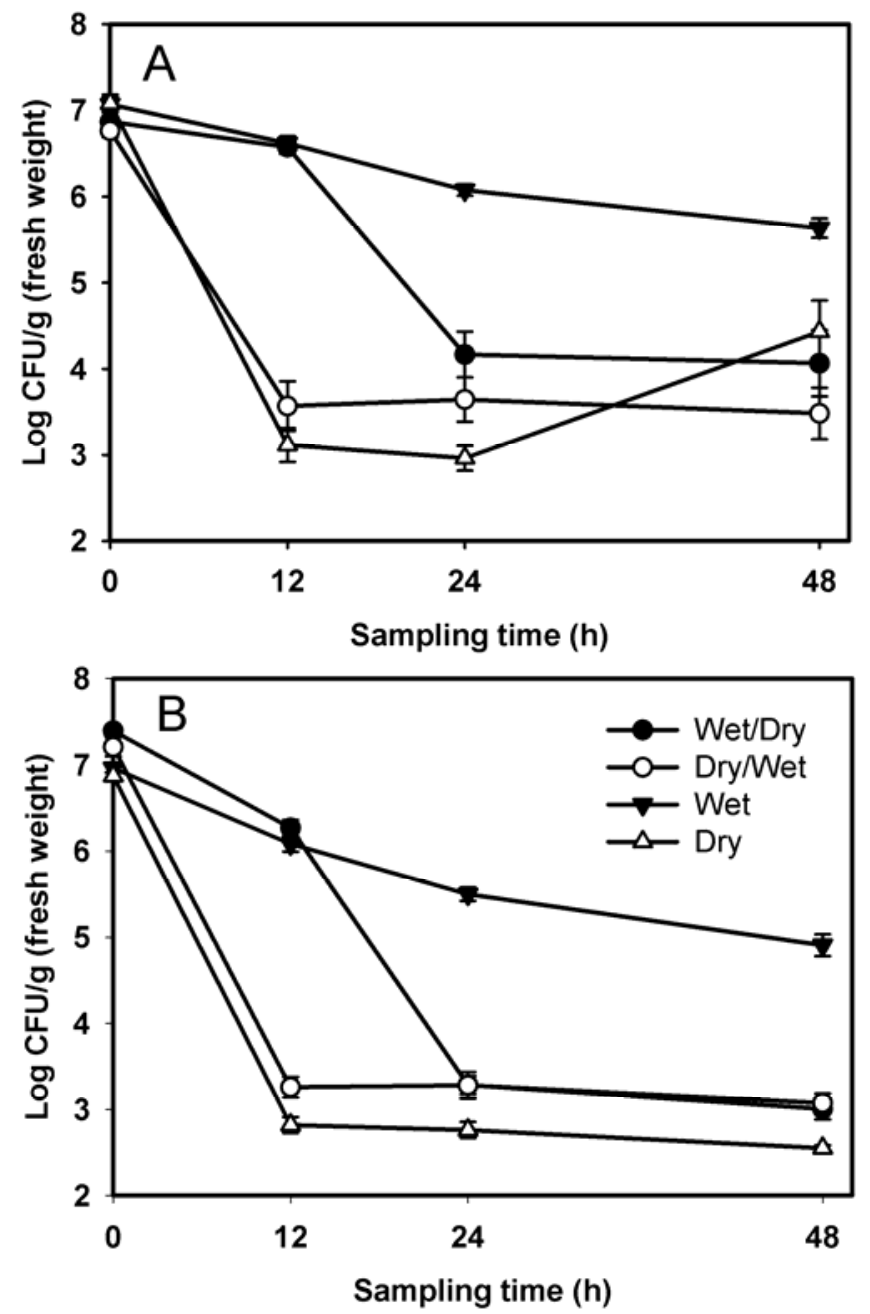

Fig. 2. Epiphytic populations (expressed as $\log _{10}$ CFU per gram of fresh leaf weight) of Erwinia tracheiphila strain SCR3 on muskmelon leaves incubated for 48 $\mathrm{h}$ at $20^{\circ} \mathrm{C}$ under alternating 12 -h periods of wet and dry conditions. The experiment was performed twice; each data point in $\mathbf{A}$, first run and $\mathbf{B}$, second run represents the mean \pm standard error of eight leaves. 
to $35^{\circ} \mathrm{C}$ is consistent with studies of other epiphytic phytopathogenic bacteria (2). Although dry conditions can impose severe stress on epiphytic bacteria $(2,26)$, E. tracheiphila populations stabilized at approximately $10^{3} \mathrm{CFU} / \mathrm{g}$ of fresh leaf tissue after 2 days of continuous dryness. Survival of E. tracheiphila under dry conditions may have resulted from selection for a subpopulation having a relatively high ability to endure water limitation (4) or occupy protected microsites on the leaf surface (28).

Our study also demonstrates that E. tracheiphila can persist on leaf surfaces in the absence of frass. Mitchell and Hanks (29) demonstrated an association between infested frass of striped cucumber beetle deposited on cucumber leaf surfaces and transmission of E. tracheiphila. Although Mitchell and Hanks did not determine how long the pathogen survived in frass, they showed that E. tracheiphila could survive in the beetle gut and in frass produced up to $24 \mathrm{~h}$ after ingestion, and that puncture inoculation of infested frass on cucumber seedlings resulted in bacterial wilt infection.

Survival of E. tracheiphila in frass could play an important role in the pathogen bacterial wilt disease cycle. It is reasonable to assume that survival of E. tracheiphila could be extended by its association with frass if substances (e.g., water or organic compounds) in the frass conferred protection against desiccation. It is also reasonable to assume that $E$. tracheiphila could be dispersed from frass by rain splash, and that this dissemination could increase the probability of contact with leaf wounds and, thereby, facilitate entry of inoculum into the plant. Sasu and co-workers (38) provided clear evidence that accumulation of infested beetle frass in floral nectaries may also lead to bacterial wilt infection. This discovery confirmed a second route for entry of the bacterial wilt pathogen in addition to entry through leaf wounds, reaffirming the importance of understanding the environmental biology of E. tracheiphila on plant surfaces.

Although our experiments were performed under controlled conditions, we showed that E. tracheiphila can persist on muskmelon leaves under conditions that resemble environmental fluctuations occurring in the field. For example, alternating 12-h wet and dry periods at $20^{\circ} \mathrm{C}$ roughly approximate conditions that occur in muskmelon production fields in the Midwest United States during the early part of the growing season (40), when plantings are at highest risk for infection by E. tracheiphila $(6,11,12,29,33)$. Taking into account the sporadic and poorly understood nature of bacterial wilt epidemics (37), a better understanding of the impact of environmental conditions on the risk of infection by epiphytic inoculum may improve management strategies and disease risk assessment.

To achieve a more realistic assessment of the role of epiphytic survival of E. tracheiphila in the bacterial wilt disease cycle, further investigation is needed (i) using more E. tracheiphila strains under a wider range of environmental conditions and longer periods, (ii) documenting survival of epiphytic populations of E. tracheiphila under field conditions, (iii) quantifying dispersal of $E$. tracheiphila on leaf surfaces by rain splash from frass, and (iv) explicitly associating circumstances (e.g., size of E. tracheiphila epiphytic populations or environmental conditions that damage leaves) with the risk of disease transmission. Our study has provided a foundation for taking the next steps in clarifying the role of epiphytic populations of E. tracheiphila in the epidemiology of this important pathosystem.

\section{Acknowledgments}

The project was funded by grants from the North Central Region IPM Center and U.S. Environmental Protection Agency Region VII Pesticide Environmental Stewardship Program (PESP). We thank A. Owens, who helped develop many of the methods used in this study; H. Li for technical assistance; and G. Beattie and P. Dixon for their helpful comments on the manuscript.

\section{Literature Cited}

1. Alder, L. S., and Hazzard, R. V. 2009. A comparison of perimeter trap crop varieties: effects on herbivory, pollination and yield in butternut squash. Environ. Entomol. 38:207-215.
2. Beattie, G. A., and Lindow, S. E. 1994. Comparison of the behavior of epiphytic fitness mutants of Pseudomonas syringae under controlled and field conditions. Appl. Environ. Microbiol.60:3799-3808.

3. Beattie, G. A., and Lindow, S. E. 1995. The secret life of foliar bacterial pathogens on leaves. Annu. Rev. Phytopathol. 33:145-172.

4. Beattie, G. A., and Lindow, S. E. 1999. Bacterial colonization of leaves: a spectrum of strategies. Phytopathology 98:353-360.

5. Brewer, M. J., Story, R. N., and Wright, V. L. 1987. Development of summer squash seedlings damaged by striped and spotted cucumber beetles (Colepotera: Chrysomelidae) Oecologia 50:370-375.

6. Brust, G. E. 1997. Interaction of Erwinia tracheiphila and muskmelon plants. Environ. Entomol.26:849-853.

7. Brust, G. E., and Foster, R. E. 1995. Semiochemical-based toxic baits for control of striped cucumber beetle (Coleoptera: Chrysomelidae) in cantaloupe. J. Econ Entomol. 88:112-116.

8. Brust, G. E., Foster, R. E., and Buhler, W. G. Comparison of insecticide use programs for managing striped cucumber beetle (Colepotera: Chrysomelidae) in muskmelon. J. Econ. Entomol. 89:981-986.

9. Burkholder, W. H. 1960. Some observations on Erwinia tracheiphila, the causal agent of the cucurbit wilt. Phytopathology 50:179-180.

10. Cavanagh, H. R., Adler L. S., and Boucher J. 2009. Using trap crops for control of Acalymma vittatum (Coleoptera: Chrysomelidae) reduces insecticide use in butternut squash. J. Econ. Entomol. 102:1101-1107.

11. deMackiewicz, D., Gildow, F. E., Blua, M., Fleischer, S. J., and Lukezic, F. L. 1998. Herbaceous weeds are not economically important reservoirs of Erwinia tracheiphila. Plant Dis. 82:521-529.

12. Fleischer S. J., deMackiewicz, D., Gildow, F. E., and Lukezic, F. L. 1999. Serological estimates of the seasonal dynamics of Erwinia tracheiphila in Acalymma vittata. Environ. Entomol. 28:470-476.

13. Fleischer S. J., Orzolek, M. D., deMackiewicz, D., and Otjen, L. 1998. Imidacloprid effects on Acalymma vittata (Coleoptera: Chrysomelidae) and bacterial wilt in cantaloupe. J. Econ. Entomol. 91:940-949.

14. Garcia-Salazar, C. G., Gildow, F. E., Fleischer, S. J., Cox-Foster, D., and Lukezic, F. L. 2000. Alimentary canal of Acalymma vittatum (Coleoptera: Chrysomelidae): morphology and potential role in the survival of Erwinia tracheiphila (Enterobacteriaceae). Can. Entomol. 132:1-13.

15. Hirano, S. S., Nordheim, E. V., Amy, D. C., and Upper, C. D. 1982. Lognormal distribution of epiphytic bacterial populations on leaf surfaces. Appl. Environ. Microbiol. 44:695-700.

16. Hodges, L., and Baxendale, F. 2007. Bee pollination of cucurbit crops. Univ. Nebr. Lincoln Ext. Bull. G1754.

17. Hoffman, M. P., Kirkwyland, J. J., Smith, R. F., and Long, R. F. 1996. Field tests with kairomone-baited traps for cucumber beetles and corn rootworms in cucurbits. Environ. Entomol. 25:1172-1181.

18. Isaacs, R., and Tuell, J. 2007. Conserving native bees on farmland. Mich. State Univ. Ext. Bull. E-2985.

19. Jesse, L., Gleason, M., Owens, A., Batzer, J., Lewis, D., and Taber, H. 2007. Use of bumble bees to extend duration of row covers on muskmelon in Iowa. In: Abstr. Ann. Meet. Entomol. Soc. Am. San Diego, CA.

20. Johnson, K. B., Sawyer, T. L., and Temple, T. N. 2006. Rates of epiphytic growth of Erwinia amylovora on flowers common in landscape. Plant Dis. 90:1331-1336.

21. Johnson, K. B., and Stockwell, V. O. 1998. Management of fire blight: a case study in microbial ecology. Annu. Rev. Phytopathol. 36:227-248.

22. Lam, W. F. 2007. An alternative sampling technique for cucumber beetles (Colepotera: Chrysomelidae) and diurnal beetle activity on muskmelon. J. Econ. Entomol. 100:823-829.

23. Latin, R. X. 1993. Diseases and pests of muskmelons and watermelons Purdue Univ. Ext. Bull. BP-44.

24. Latin, R. X. APSnet Features. Bacterial Wilt. October 2000. http://www. apsnet.org/publications/apsnetfeatures/Pages/BacterialWilt.aspx

25. Leach, J. G. 1964. Observations on cucumber beetles as vectors of cucurbit wilt. Phytopathology 54:606-607.

26. Leben, C. 1988. Relative humidity and the survival of epiphytic bacteria with buds and leaves of cucumber plants. Phytopathology 78:179-185.

27. Lewis, P. A., Lampman, R. L., and Metcalf, R. L. 1990. Kairomonal attractants for Acalymma vittatum (Coleoptera: Chrysomelidae). Environ. Entomol. 19:8-14

28. Lindow, S. E., and Brandl, M. T. 2003. Minireview: microbiology of the phyllosphere. Appl. Environ. Microbiol. 69:1875-1883.

29. Mitchell, R. F., and Hanks, L. M. 2009. Insect frass as a pathway for transmission of bacterial wilt of cucurbits. Environ. Entomol. 38:395-403.

30. Mueller, D. S., Gleason, M. L., Sisson, A. J., and Massman, J. M. 2006. Effect of row covers on suppression of bacterial wilt of muskmelon in Iowa. Plant Health Progress. Online publication. doi:10.1094/PHP-2006-1020-02-RS.

31. NASS (National Agricultural Statistics Survey). 2010. USDA Vegetable 2009 Annual Summary. Vg1-2 (10).

32. Pair, S. D. 1997. Evaluation of systemically treated squash trap plants and attracticidal baits for early-season control of striped and spotted cucumber beetles (Coleoptera: Chrysomelidae) and squash bug (Hemiptera: Coreidae) in cucurbit crops. J. Econ. Entomol. 90:1307-1314.

33. Rand, F. V., and Cash, L. 1920. Some insect relations of Bacillus tracheiphilus Erw. Sm. Phytopathology 10:133-140.

34. Rand, F. V., and Enlows, E. M. A. 1916. Transmission and control of bacte- 
rial wilt of cucurbits. J. Agric. Res. 6:417-434.

35. Rouse, D. I., Nordheim, E. V., Hirano, S. S., and Upper, C. D. 1985. A model relating the probability of foliar disease incidence to the population frequencies of bacterial plant pathogens. Phytopathology.75:505-509.

36. Saalau-Rojas, E. 2010. Bacterial wilt of cucurbits: assessment of row covers in disease management, and of epiphytic survival and genetic diversity of the pathogen, Erwinia tracheiphila. M.S. thesis. Iowa State University, Ames.

37. Saalau Rojas, E., Gleason, M. L., Batzer, J. C., and Duffy, M. 2011. Feasibility of delaying removal of row covers to suppress bacterial wilt of muskmelon (Cucumis melo). Plant Dis. 95:729-734.

38. Sasu, M. A., Seidl-Adams, I., Wall, K., Winsor, J. A., and Stephenson, A. G.
2010. Floral transmission of Erwinia tracheiphila by cucumber beetles in a Wild Cucurbita pepo. Envrion. Entomol. 39:140-148.

39. Schroth, M. N., Thomson, S. V., Hildebrand, D. C., and Moller, W. J. 1974.Epidemiology and control of fire blight. Annu. Rev. Phytopathol. 12:389-412.

40. Sentelhas, P. C., Dalla Marta, A., Orlandini, S., Santos, E. A., Gillespie, T. J., and Gleason, M. L. 2008. Suitability of relative humidity as an estimator of leaf wetness duration. Agric. For. Meteorol. 148:392-400.

41. Sherf, A. F., and MacNab, A. A. 1986. Cucurbits. Pages 307-311 in: Vegetable Diseases and Their Control. Wiley, New York.

42. Steiner, P. W. 1990. Predicting apple blossom infections by Erwinia amylovora using the MARYBLYT model. Acta Hortic. 273:139-148. 